\title{
UNIVERSITY OF ROME CARBON-14 DATES III
}

\author{
M. ALESSIO, F. BELLA
}

Istituto di Fisica, Università di Roma. Istituto Nazionale di Fisica Nucleare, Sezione di Roma

\section{F. BACHECHI and C. CORTESI}

Istituto di Geochimica, Università di Roma

The following list comprises age measurements carried out between December 1963 and September 1964. The samples dated are almost all of archaeological interest and are drawn from Italian and Egyptian territory.

The pretreatment of samples, the production of pure $\mathrm{CO}_{2}$ and the counting techniques have been described elsewhere (Bella and Cortesi, 1960; Alessio, Bella and Cortesi, 1964). All dates were calculated on the basis of two to eight values, obtained from different measurements of each sample. With only one exception (see comment on sample R-93 in the following date list) the errors quoted are the $1 \sigma$ statistical errors, which in the measurements here reported are of the same order as the "experimental error" (Crevecoeur, Vander Stricht and Capron, 1959).

Ages have been calculated using Libby's half-life of $5568 \pm 30 \mathrm{yr}$ with 1950 as the standard year of reference. As for the measurements of Rome II (1964), a modern wood grown near Rome between 1949 and 1953 has been used as modern standard. Its activity was checked again by measurements of known age samples and judged satisfactory.

\section{ACKNOWLEDGMENTS}

Our thanks are due to the Consiglio Nazionale delle Ricerche which has provided partial financial support.

\section{SAMPLE DESCRIPTIONS}

\section{ARCHAEOLOGIC SAMPLES}

\section{A. Italy}

\section{R-95. Grotta Aisone}

Charcoal from deposit in small cave or shelter of Aisone, Valle Stura, province of Cuneo, Piedmont $\left(44^{\circ} 19^{\prime} \mathrm{N}\right.$ Lat, $7^{\circ} 13^{\prime} \mathrm{E}$ Long, $850 \mathrm{~m}$ above sealevel). Excavated, coll. 1956 and subm. 1957 by E. Rittatore, Gabinetto di Paletnologia, Univ. of Milan. Pottery belonging to Danubian square-mouthed pot Culture, Middle Neolithic, and a child's tomb were discovered in deposit (Radmilli, 1960). Comment: age obtained agrees with that expected for culture discovered in the deposit.

\section{R-27. Bec Berciassa}

$2190 \pm 65$

240 B.C.

Charcoal collected in Late Iron Age hut settlement on southern side of mountain Bec Berciassa, Roccavione, Val Vermenaga, province of Cuneo, 
Piedmont $\left(44^{\circ} 19^{\prime} \mathrm{N}\right.$ Lat, $7^{\circ} 29^{\prime} \mathrm{E}$ Long, $970 \mathrm{~m}$ above sealevel $)$. The only remains of the huts are floors of piled earth containing sherds, bones of wild and domestic animals, and charcoal. Discovery occurred of plentiful domestic pottery, belonging to Golasecca Culture which existed in Piedmont, Lombardy and Canton Ticino (Rittatore, 1952a,b,c). Excavated 1932-1952 by F. Rittatore and L. Cardini. Coll. and subm. 1953 by L. Cardini, Ist. Italiano di Paleontologia Umana. Comment: date obtained agrees with last manifestations of Iron Age in Italy.

\section{Cà Morta series}

Charcoal mixed with carbonous soil from Iron Age tombs of Cà Morta necropolis near Camerlata, $3.5 \mathrm{~km} \mathrm{~S}$ of Como, Lombardy $\left(45^{\circ} 45^{\prime} \mathrm{N}\right.$ Lat, $9^{\circ}$ 05' E Long). Excavation 1956-57 by E. Rittatore who coll. 1956 and subm. 1957 through the interest of the late A. C. Blanc, Ist. Italiano di Paleontologia Umana. Necropolis contains cinerary tombs of various types and was in use during a millennium from end of Bronze Age to 1st century of Roman Empire (Barsega, 1916, 1919-2la,b and 1922; Randall-MacIver, 1927). Charcoal was found in the earth filling four pit-shaped cinerary tombs, scattered around pottery and bronze objects. The four tombs have been judged to be contemporaneous, and belong to 2nd phase of Golasecca culture, for which Cà Morta is considered the most important necropolis (Rittatore, 1956, 1958). As tombs were not far below surface, rootlets had penetrated into pottery objects.

\section{R-94A. Cà Morta 1}

$$
\mathbf{2 0 5 0} \pm \mathbf{5 0}
$$

100 в.C.

Charcoal from tombs no. 9, 11, and 18. Owing to the nature of the material, earth has only been roughly separated.

\section{R-94B. Cà Morta 2}

$$
\mathbf{2 4 4 0} \pm \mathbf{5 5}
$$

Pure charcoal carefully selected from tomb no. 16.

General Comment: age of R-94B agrees fairly closely with archaeological date. R-94A proved younger probably because of contamination that could not be eliminated by pretreatment.

\section{Isolone delle Moradelle or Isolone del Mincio series}

Fragments of wooden piles from lake dwellings of Isolone delle Moradelle in the river Mincio, downstream from Valeggio, $4 \mathrm{~km} \mathrm{E}$ of Volta Mantovana. province of Mantua, Lombardy $\left(45^{\circ} 19^{\prime} \mathrm{N}\right.$ Lat, $10^{\circ} 43^{\prime} \mathrm{E}$ Long). Coll. and subm. 1957 by E. Rittatore through the interest of the late A. C. Blanc. Isolone del Mincio was artificial island formed around wooden piles; it was destroyed in 1956-1957. Excavation carried out at that time by Soprintendenza alle Antichità della Lombardia and by E. Rittatore brought to light wooden piles dating from Late Bronze Age: three distinct layers of dwellings were discovered (Mirabella Roberti, 1956). The wood, id. by Villaret von Rochov (1958), was impaired and eaten into by rootlets picked out by hand as far as possible.

\section{R-96. Isolone del Mincio 1}

$3230 \pm 60$

Part of wooden pile from lower layer of dwellings. 


\section{R-97. Isolone del Mincio 2}

Part of wooden pile from middle layer of dwellings.

\section{R-98. Isolone del Mincio 3}

Part of wooden pile from upper layer of dwellings.

1125 B.c.

General Comment: R-96 and R-98 dates agree with archaeological age and are an indication of length of settlement. Age measurements at Pisa of other fragments of piles from same two layers were: Pi-25, $3333 \pm 115 ; \mathrm{Pi}-26,3100 \pm$ 113 (Pisa I). Age of R-97 proved inexplicably too early.

\section{R-25. Cavriana}

Darkened, partially charred wood from dwellings built on horizontal wooden packwork, so-called "bonifica," in peat-bog of Bande di Cavriana, 37 $\mathrm{km} \mathrm{N}$ of Mantua, Lombardy $\left(45^{\circ} 21^{\prime} \mathrm{N}\right.$ Lat, $10^{\circ} 37^{\prime} \mathrm{E}$ Long). Excavated 1952 by E. Rittatore who coll. 1952; subm. 1953 by L. Cardini. Pottery and other material belonging to Lower-Middle Bronze Age, Polada Culture, have been found (Rittatore, 1953). Comment: wood from dwelling on "bonifica" at Barche di Solferino, $27 \mathrm{~km} \mathrm{NW}$ of Mantua together with archaeological finds helonging to Polada Culture have been dated at Pisa; age is in agreement: Pi-87, $3341 \pm 115$ (Pisa II).

\section{R-109. Grotta Arma dello Stefanin}

Charcoal from Layer IV of Grotta Arma dello Stefanin deposit, Val Pennavaira, province of Savona, Liguria $\left(44^{\circ} 06^{\prime} 13^{\prime \prime} \mathrm{N}\right.$ Lat, $8^{\circ} 00^{\prime} 57^{\prime \prime} \mathrm{E}$ Long, $440 \mathrm{~m}$ above sealevel). Cave no. 257 in "Catalogo Speleologico Ligure." Coll. 1957 and subm. 1958 by M. Leale Anfossi, Ist. Italiano di Paleontologia Umana. Throughout deposit, various hearths, charred bones of wild animals, food refuse, have been found. Level III contains pottery dating from Lower Neolithic and Iron Ages; Levels IV and V contain a number of flint instruments with characteristics of a final Upper Paleolithic or Epipaleolithic industry. An industry that can be assigned to Upper Paleolithic has been found in Layers IX and X. Indications given here as regards the cultures are general ones since both pottery and industries are still being examined (Leale Anfossi. 1953, 1956, 1958-61a, 1958-61b). Comment: age obtained for Level IV would agree with a rather late Epipaleolithic industry. Dating of other levels is being carried out.

\section{R-80. Soragna}

$470 \pm 45$

\section{A.D. 1480}

Partially charred wood found at depth of ca. $4 \mathrm{~m}$ during excavation near Soragna $20 \mathrm{~km} \mathrm{NW}$ of Parma, Emilia (44. $56^{\prime} \mathrm{N}$ Lat, $10^{\circ} 07^{\prime} \mathrm{E}$ Long). Coll. and subm. 1956 by G. Monaco, Soprintendenza alle Antichità dell'Emilia e Romagna. Comment: besides $\mathrm{C}^{14}$ age, there are not yet other elements for dating this wood. 


\section{R-5. Valle Trebba}

Wood excavated in Valle Trebba, ca. $5.5 \mathrm{~km} \mathrm{NW}$ of Comacchio, province of Ferrara ( $44^{\circ} 46^{\prime} \mathrm{N}$ Lat, $12^{\circ} 08^{\prime} \mathrm{E}$ Long), and housed in premises of Soprintendenza alle Antichità dell'Emilia e Romagna at Bologna. Subm. 1952 by the late S. Aurigemma, formerly Soprintendente alle Antichità dell'Emilia e Romagna. Comment: wood believed to belong to lake-dwelling of 5th to 3rd centuries B.c. Owing to uncertain attribution, $\mathrm{C}^{14}$ date was requested. Age obtained refutes attribution.

\section{R-26. Firenze}

$1935 \pm 55$

Charcoal found together with human bones and Roman pottery from Roman layer of end of 2nd or beginning of lst century A.D. (Maetzke, 1950), Via Por Santa Maria, Florence $\left(43^{\circ} 46^{\prime} 22^{\prime \prime} \mathrm{N}\right.$ Lat, $11^{\circ} 16^{\prime} 16^{\prime \prime}$ E Long). Coll. 1950 and subm. 1953 by L. Cardini. Roman layer was discovered during 1950 excavation in area of war-destroyed buildings now partially occupied by trade stock-exchange. Comment: date agrees well with expected historical age.

\section{Etruscan Ovens series}

Charcoal from Etruscan ovens, Valle del Temperino $1 \mathrm{~km} \mathrm{~N}$ of Campiglia Marittima, province of Leghorn, Tuscany $\left(43^{\circ} 03^{\prime} \mathrm{N}\right.$ Lat, $10^{\circ} 10^{\prime} \mathrm{E}$ Long). Coll. 1936 and subm. 1951 by E. Tongiorgi, Lab. di Geologia Nucleare, Univ. of Pisa.

\section{R-10A. Etruscan Oven no. 2}

$$
\begin{gathered}
2175 \pm 45 \\
225 \text { в.c. } \\
2250 \pm 45
\end{gathered}
$$

R-10B. Etruscan Oven no. 4

Comment: Commission for study of Old Mine Working Activities of Soprintendenza alle Antichità dell'Etruria excavated six Etruscan ovens in this locality in 1936. They were identified through study of the slag as copper manufacturing furnaces. Charcoal belongs to Quercus robur, Quercus cerris and Pirus aucuparia (Tongiorgi, 1937). Previous date of charcoal from oven no. 3, R-10, $2140 \pm 65$ (Rome II), and the present dates are in agreement, confirming that ovens belonged to last phase of Etruscan civilization. No archaeological find had indicated historical date of ovens (D'Achiardi and Stefanini, 1937).

\section{R-6. Necropolis of Cerveteri}

Charcoal from foculus of tomb no. 2 of Maroi Tumulus, Etruscan Necropolis of Cerveteri, locality of Banditaccia, $3 \mathrm{~km} \mathrm{~N}$ of Cerveteri, Lazio $\left(42^{\circ} 00^{\prime}\right.$ $\mathrm{N}$ Lat, $12^{\circ} 05^{\prime} \mathrm{E}$ Long). Tumulus excavated 1951-1953 by M. Moretti, present Soprintendente alle Antichità dell'Etruria Meridionale. Coll. and subm. 1952. by M. Moretti through the interest of the late R. Bartoccini, formerly Soprintendente alle Antichità dell'Etruria Meridionale. Necropolis was in use from beginning of 7 th century в.c. until 2nd-1st century в.c. The Maroi Tumulus, a 
notable monument, has been dated end of 6th century B.c. on basis of characteristics of Etruscan objects found in it and presence of three Attic vases decorated with black figures. Foculus also contained remnants of a funeral meal (Moretti, in preparation). Charcoal finds in Etruscan tombs are very rare. Comment: age obtained agrees well with archaeological date. Previous date at Rome with a solid carbon counter gave $2730 \pm 240$ (Ballario et al., 1955).

\section{Grotta Misa series}

Charcoal and burnt Triticum sativum and Panicum miliaceum (id. by E. Tongiorgi) from Grotta Misa deposit, Ischia di Castro, province of Viterbo, Lazio $\left(42^{\circ} 30^{\prime} \mathrm{N}\right.$ Lat, $11^{\circ} 38^{\prime} \mathrm{E}$ Long). Excavated 1947 by L. Cardini, F. Rittatore and E. Tongiorgi. Late Bronze Age Culture is represented in deposit by bronze objects and pottery (Rittatore, 1949).

\section{R-9. Grotta Misa 1 (remeasured)}

$2870 \pm 60$

Charcoal coll. 1947 and subm. 1951 by E. Tongiorgi.

920в.C.

\section{R-24. Grotta Misa 2}

Burnt wheat and millet coll. 1947 and subm. 1953 by L. Cardini. General Comment: charcoal from same deposit has been dated at Pisa, Pi-54, $3030 \pm 75$ (Pisa II). New measurements at Rome are in closer agreement with Pisa date and culture contained in deposit. First date for R-9 was $2460 \pm$ 100 (Rome II).

\section{R-32. Sasso di Furbara}

Wood-carbonaceous material together with clayey soil found in tomb no. 4 of Caolino Necropolis, Sasso di Furbara, Via Aurelia, $60 \mathrm{~km}$ from Rome $\left(42^{\circ}\right.$ $03^{\prime} \mathrm{N}$ Lat, $12^{\circ} 02^{\prime} \mathrm{E}$ Long). Excavated by A. M. Radmilli and S. Patrizi 1949-1956 and by D. Brusadin since 1957. Coll. and subm. 1954 by the late S. Patrizi, Ist. Italiano di Paleontologia Umana. Iron Age mixed rite necropolis consisting mainly of inhumation tombs (like tomb no. 4). Archaeological finds attributable to 2nd period of "Tarquinia Series," southern facies of Villanovian. However, owing to probable presence of a gold object, tomb no. 4 seems later and might be assigned to Tarquinia III (Brusadin, 1964, private commun.). Comment: age obtained also compatible with later date (Tarquinia III).

\section{R-117. Leporano, Porto Perone \\ $3100 \pm 60$ 1150 в.с.}

Charcoal from prehistoric station of Porto Perone near Leporano, ca. 16 $\mathrm{km}$ SE of 'Taranto, Apulia $\left(40^{\circ} 23^{\prime} \mathrm{N}\right.$ Lat, $17^{\circ} 19^{\prime} \mathrm{E}$ Long). Excavated, coll. August 1958 and subm. Nov. 1958 by F. G. Lo Porto and Soprintendenza alle Antichità della Puglia e del Materano. Further excavation carried out in 1960. Bronze Age huts and remains of Iron Age dwellings have been found in the station (Lo Porto, 1960). Charcoal was discovered under the piled earth floor of the hut at depth of from 10 to $20 \mathrm{~cm}$ in a "black layer." Comment: age agrees with Late Bronze Age. 


\section{R-54. Grotta Romanelli}

$9050 \pm 100$

7100 в.C.

Humic acids extracted from top layer $(0$ to $5 \mathrm{~cm})$ of "terra bruna" formation of deposit in Grotta Romanelli, Costiera Salentina, $2 \mathrm{~km}$ from Castro towards S. Cesarea, province of Lecce, Apulia $\left(40^{\circ} 01^{\prime} \mathrm{N}\right.$ Lat, $18^{\circ} 24^{\prime}$ E Long). Coll. and subm. by the late A. C. Blanc and L. Cardini. Comment: G. A. Blanc's interpretation of Grotta Romanelli deposit and measurements carried out at Rome and Groningen of charcoal and humus from other levels of "terra bruna" formation have been illustrated and discussed in the preceding date list (Alessio, Bella and Cortesi, 1964: see R-58, p. 79-80). Age of R-54 seems too recent if compared with ages obtained for R-58 and R-56 (humus and charcoal from same level $30 \mathrm{~cm}$ below surface) and suggests surface contamination, probably by small animals, of the palaeosoil humus.

\section{R-28. Megara Hyblaea}

$2350 \pm 65$

400 в.C.

Charcoal found in 7th century B.c. layer during excavation 1949-1959, directed by F. Villard, of the ancient Megara Hyblaea near Augusta, province of Syracuse, Sicily ( $37^{\circ} 12^{\prime} \mathrm{N}$ Lat, $17^{\circ} 19^{\prime} \mathrm{E}$ Long). Coll. by F. Villard, Ecole Française de Rome, and subm. 1953 by L. Cardini. Megara Hyblaea was founded by the Greeks at end of 8th century B.c. on remains of Neolithic village belonging to Stentinello Culture; it flourished from 7th to beginning of 5 th century B.C. when it was destroyed. A Hellenistic village was built on its ruins around 330 B.C., and site was later inhabited by the Romans till the time of Constantine. Comment: date obtained does not agree with expected historical age.

\section{R-93. Statue}

$200 \pm 200$

Fragments of cedar wood from female statue apparently found in river at mouth of Tiber and reckoned to be part of prow decorations (figure-head) of Roman ship of Late Roman Empire (4th-5th centuries A.D.). Subm. 1956 by U. Lumini, Soprintendenza alle Antichità delle provincie di Firenze, Arezzo e Pistoia, through the interest of M. Salmi, Ist.di Storia dell'Arte, Univ. of Rome. Comment: attribution based on stylistic features of statue and on state of wood which bears traces of long immersion in fresh water. Different measurements of sample did not agree well enough to permit statistical treatment of the results, so error in this dating is a maximum error. Age obtained refutes attribution, the statute being of more recent date.

\section{R-130. Mortar}

$13,170 \pm 175$

\section{1,220 в.C.}

Mortar containing $30 \% \mathrm{CaCO}_{3}$ from historical building, locality not communicated; expected age 2000-2500 yr B.P. Subm. 1959 by Padre Cristoforo O. F. M. Cap. Comment: many times our lab. has been asked if it is possible to date buildings, monuments etc. by measuring activity of carbon of $\mathrm{CaCO}_{3}$ formed during carbonation by atmospheric $\mathrm{CO}_{2}$ of lime contained in the mortar used. We have always made it clear that such dating was only theoretically possible and that the following quite improbable conditions would have to exist: 
a) complete decomposition of limestone roasted in limekiln in order to manufacture quicklime; b) absence of carbonate materials among the other component of the mortar; c) no subsequent exchanges between the $\mathrm{CaCO}_{3}$ formed throughout hardening of the lime and atmospheric and water $\mathrm{CO}_{2}$. Nevertheless, as this request was repeated with insistence, activity of this mortar was measured and, as it was to be expected, age obtained was completely fortuitous and meaningless owing to an unverifiable combination of the disturbance factors mentioned.

$$
\text { B. Egypt }
$$

\section{R-33. Kau-el-Kebir}

$$
\begin{array}{ll} 
& 3300 \pm 50 \\
& 1350 \text { в.с. } \\
& 3290 \pm 60 \\
& 1340 \text { в.c. } \\
\text { average } & 3300 \pm 40 \\
& 1350 \text { в.C. }
\end{array}
$$

Wood fragments in excellent state of preservation presumably from coffin of tomb excavated by E. Schiaparelli at Kau-el-Kebir, Upper Egypt $\left(26^{\circ} 50^{\prime}\right.$ N Lat, $31^{\circ} 32^{\prime}$ E Long), housed in Museo Egizio, Turin. Subm. 1954 by E. Scamuzzi, Soprintendente alle Antichità, Egittologia, Torino II. Comment: tomb is thought to belong to Middle Kingdom and attributed to period 2000. 1800 B.c. Age obtained is significantly younger than expected.

\section{R-36. Thebes}

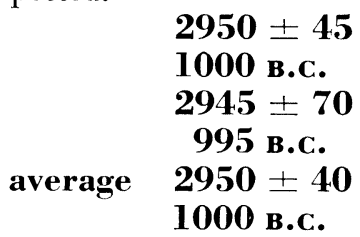

Well-preserved sycamore wooded fragments from anonymous tomb. Thebes, Valley of the Queens, Upper Egypt ( $25^{\circ} 44^{\prime} \mathrm{N}$ Lat, $32^{\circ} 38^{\prime} \mathrm{E}$ Long). housed in Museo Egizio, Turin. Subm. 1954 by E. Scamuzzi. Comment: estimated age, Ramses II, XIXth Dynasty 1300 to 1235 в.C.; date is somewhat younger.

\section{R-38. Egypt}

$$
\begin{array}{ll} 
& 3320 \pm 60 \\
& 1370 \text { в.c. } \\
& 3000 \pm 75 \\
& 1050 \text { в.c. } \\
\text { average } & 3200 \pm 45 \\
& 1250 \text { в.c. }
\end{array}
$$

Wooden fragment from coffin; original location in Egypt is not known; housed in Museo Egizio, Turin. Subm. 1954 by E. Scamuzzi. Comment: sample is classified as belonging to Middle Kingdom 2100 to 1580 B.c.; age obtained is younger than expected.

General Comment: dates of 54 archaeological and historical samples from Egypt were published up to the summer of 1964. Some of these have been repeatedly dated both by the same lab. and as cross-check samples (C-1, C-62, C-81, Gro-1100, Gro-1109, BM-27) ; for all samples dated see: Libby, 1955; 
Suess, 1960; British Museum I, II, III; Groningen I, II, III; Uppsala I; UCLA I, II; Arizona III, IV; Pennsylvania III; USGS V; Rome, I, II; Louvain II; Saclay I; Sharp Labs. I; Tata Inst. I. These measurements have shown that most Egyptian samples give a $\mathrm{C}^{14}$ age which is less than expected historical age often based on astronomical evidences. No satisfactory physical or archaeological explanation of this fact yet found, except a physical attempt by Damon and Long (1963).

\section{GEOLOGIC SAMPLES}

\section{Italy}

\section{R-39. Massaciuccoli, peat pebble (remeasured) $\quad 18,550 \pm 400$}

Pebble of compressed and hardened peat perforated by pholads, Lago di Massaciuccoli near Torre del Lago, Bassa Versilia, Tuscany $\left(43^{\circ} 50^{\prime} \mathrm{N}\right.$ Lat, $10^{\circ} 09^{\prime} \mathrm{E}$ Long). Subm. 1954 by the late A. C. Blanc. Comment: for origin and significance of the sample see Alessio, Bella and Cortesi (1964, p. 87). New date agrees with preceding one: R-39, 18,800 \pm 400 (Rome II), and thus confirms Main Würm age of sample.

\section{CROSS-CHECK SAMPLES}

\section{R-64. Ruds Vedby (remeasured)}

Wood from thin, dark layer of peaty lake mud forming pollen-zone boundary II/III, Alleröd-Younger Dryas; Ruds Vedby, Zealand, Denmark ( $55^{\circ} 32^{\prime}$ $\mathrm{N}$ Lat, $11^{\circ} 22^{\prime} \mathrm{E}$ Long). Distributed by H. Tauber as cross-check sample (K-101). Comment: dates of K-101, published up to end of 1963 by many European labs. and by USGS, are listed and discussed in Alessio, Bella and Cortesi (1964, p. 78). Subsequently Copenhagen remeasured the sample: K-101, 10,970 \pm 120 (Copenhagen VI), obtaining a date in agreement with previous ones. The new Rome date agrees with that of Copenhagen and Groningen, the previous one being too old: R-64, 11,900 \pm 170 (Rome II); average of the previous and present date is $11,500 \pm 110$.

Date lists:

\begin{tabular}{|c|c|}
\hline Arizona III & Damon and Long, 1962 \\
\hline Arizona IV & Damon, Long, and Sigalove, 1963 \\
\hline British Museum I & Barker and Mackey, 1959 \\
\hline British Museum II & Barker and Mackey, 1960 \\
\hline British Museum III & Barker and Mackey, 1961 \\
\hline Copenhagen VI & Tauber, 1964 \\
\hline Groningen I & de Vries and Barendsen, 1954 \\
\hline Groningen II & de Vries, Barendsen, and Waterbolk, 1958 \\
\hline Groningen III & de Vries and Waterbolk, 1958 \\
\hline Louvain II & Deumer, Gilot, and Capron, 1964 \\
\hline Pennsylvania III & Ralph, 1959 \\
\hline Pisa I & Ferrara, Reinhartz, and Tongiorgi, 1959 \\
\hline Pisa II & Ferrara, Fornaca-Rinaldi, and Tongiorgi, 1961 \\
\hline Rome I & Bella and Cortesi, 1957 \\
\hline Rome II & Alessio, Bella, and Cortesi, 1964 \\
\hline Saclay I & Delibrias, Guillier, and Lebeyrie, 1964 \\
\hline Sharp Laboratories I & Ellis and Sharp, 1964 \\
\hline
\end{tabular}


Tata Institute I

UCLA I

UCLA II

Uppsala I

Kusumgar, Lal, and Sarna, 1963

USGS V

Fergusson and Libby, 1962

Fergusson and Libby, 1963

Olsson, 1959

Rubin and Alexander, 1960

Alessio, M., Bella, F., and Cortesi, C., 1964, University of Rome carbon-14 dates II: Radiocarbon, v. 6, p. 77-90.

Ballario, C., Beneventano, M., De Marco, A., Magistrelli, F., Cortesi, C., and Mantovani, T., 1955, Apparatus for carbon-14 dating: Science, v. 121, p. 409-412.

Barker, H., and Mackey, C. J., 1959, British Museum natural radiocarbon measurements I: Am. Jour. Sci. Radioc. Supp., v. 1, p. 81-86. 1960, British Museum natural radiocarbon measurements II: Am. Jour. Sci.

v. 3, p. 39-45. British Museum natural radiocarbon measurements III: Radiocarbon,

arsega, G., 1916, Antichità preromane alla Cà Morta: Riv. di Archeologia di Como, fasc. $73-75$, p. $44-58$.

1919-21a, Tombe della prima Età del Ferro a Mariano Comense, Cantù, Cà Morta e Lasa: Riv. di Archeologia di Como, fasc. 79-81, p. 42-58.

1919-21b, Nuove scoperte ad Albate e alla Cà Morta ed il periodo di transizione dal bronzo al ferro nei dintorni di Como: Riv. di Archeologia di Como, fasc. 79-81, p. $18-32$. 1922, Nuove tombe alla Cà Morta, palette sacrali e frammenti di tessuto
preistorico: Riv. di Archeologia di Como, fasc. 82-84, p. 121-131.

Bella, F., and Cortesi, C., 1957, Attività del laboratorio dell'Università di Roma per le datazioni con il $\mathrm{C}^{14}:$ Ricerca Scientifica, v. 27 , p. 2677-2680.

1960, The $\mathrm{CO}_{2}$-proportional counter of the carbon-14 dating laboratory of the University of Rome: Ricerca Scientifica, v. 30, p. 1969-1977.

Crevecoeur, C. H., Vander Stricht, A., and Capron, P. C., Precision of the dating method. Standardization of the calculation of the errors and the maximum age in the $C^{14}$ method: Acad. Royale Belgique Bull. Cl. Sci., v. 45, p. 876-890.

D'Achiardi, G., and Stefanini, G., 1937, Ricerche archeologico-minerarie in Val Fornaciaia: Studi Etruschi, v. 11, p. 305-341.

Damon, P. E., and Long, A., 1962, Arizona radiocarbon dates III: Radiocarbon, v. 4, p. $239-249$.

- 1963, Carbon-14, carbon dioxide and climate: to be presented at Internat. Union Geod. Geoph., XIII Gen. Ass., Berkeley, California, Aug. 19-31.

Damon, P. E., Long, A., and Sigalove, J. J., 1963, Arizona radiocarbon dates IV: Radiocarbon, v. 5 , p. $283-301$.

Delibrias, G., Guillier, M. T., and Labeyrie, J., 1964, Saclay natural radiocarbon measurements I: Radiocarbon, v. 6, p. 233-250.

Deumer, J. M., Gilot, E., and Capron, P. C., 1964, Louvain natural radiocarbon measurements II: Radiocarbon, v. 6, p. 160-166. Ellis, J. G., and Sharp, R. A., 1964, Sharp laboratories measurements I: Radiocarbon,
v. 6, p. 108-109.

Fergusson, G. J., and Libby, W. F., 1962, UCLA radiocarbon dates I: Radiocarbon, v. 4, p. 109-114.

1963, UCLA radiocarbon dates II: Radiocarbon, v. 5, p. 1-22.

Ferrara, G., Reinharz M., and Tongiorgi, E., 1959, Carbon-14 dating in Pisa: Am. Jour. Sci. Radioc. Supp., v. 1, p. 103-110

Ferrara, G., Fornaca-Rinaldi, G., and Tongiorgi, E., 1961, Carbon-14 dating in Pisa-II: Radiocarbon, v. 3, p. 99-104.

Kusumgar, S., Lal, D., and Sarna, R. P., 1963, Tata Institute radiocarbon date list I: Radiocarbon, v. 5, p. 273-282.

Leale Anfossi, M., 1953, Nuove ricerche preistoriche in Val Pennavaira: Riv. Ingauna e Intemelia, n.s., v. 8, p. 65-67.

Pennavas6, Industria epipaleolitica a microliti nell'Arma dello Stefanin (Val Pennavaira-Albenga ): Quaternaria, v. 3, p. 256-257.

Pennavaira-Albenga) Campagna di scavi sistematici all'Arma dello Stefanin (Val ( 348. p. $357-359$.

Libby, W. F., 1955, Radiocarbon Dating: Chicago, 2nd ed., Univ. of Chicago Press, p. 77-79.

Lo Porto, F. G., 1960, Notiziario: Puglie, Leporano (Taranto) : Riv. Scienze Preistoriche, v. 15, p. 235. 
Maetzke, G., 1950, Osservazioni sulle recenti ricerche nel sottosuolo di Firenze: Atti Accademia Fiorentina Scienze Morali, la Colombaria, Firenze, p. 183-190.

Mirabella Roberti, M., 1956, Una palafitta fluviale a sud di Valeggio sul Mincio: Ist. Lombardo sci. e lettere. Convegno di studi rapporti scient. cultur. italo-svizzeri Atti, p. 118.

Olson, I., 1959, Uppsala natural radiocarbon measurements I: Am. Jour. Sci. Radioc. Supp., v. 1, p. 87-102.

Radmilli, A., 1960, La preistoria della Lombardia e del Piemonte: L'Universo, v. 40, p. $121-142$.

Ralph, E. K., 1959, University of Pennsylvania radiocarbon dates III: Am. Jour. Sci. Radioc. Supp., v. 1, p. 45-58.

Randall-MacIver, D., 1927, The Iron age in Italy: Oxford, Clarendon Press, p. 84-87.

Rittatore, E., 1949, Lo scavo di un deposito dell' età del Bronzo a Grotta Misa in Etruria: Atti I ${ }^{\circ}$ Congresso Preistorico italo-svizzero, Como, p. 85-90.

1952a, Ricerche paletnologiche nel territorio di Cuneo: Boll. Soc. Studi Storici, Archeologici ed Artistici, Provincia di Cuneo, v. 30, p. 96-100. 1952b, Nuovi scavi alla stazione all' aperto di Bec Berciassa: Boll. Soc. Studi Storici, Archeologici ed Artistici, Provincia di Cuneo, v. 31, p. 49-51. 1952c, Ricerche sull' Età del Ferro nel Cuneese: Rivista Studi Liguri, v. 18, p. $34-41$. p. $131-144$

1954, Contributi di recenti ricerche paletnologiche in Italia: Origines, Como, 1956, Tombe preromane scoperte alla Cà Morta: Riv. di Archeologia di Como, fasc. 138, p. 8 .

1958. Tombe preromane scoperte alla Cà Morta: Riv. di Archeologia, Provincia di Como, fasc. 140 , p. 16.

Rubin, M., and Alexander, C., 1960, U. S. Geological Survey radiocarbon dates V: Radiocarbon, v. 2, p. 129-185.

Suess, H. E., 1960, Secular changes in the concentration of atmospheric radiocarbon: Natl. Acad. Sci.: Natl. Res. Council Pub. 845 (Nuclear Sci. Ser. no. 33), p. 90-94.

Tauber, H., 1964, Copenhagen radiocarbon dates VI: Radiocarbon, v. 6, p. 215-225.

Tongiorgi, E., 1937, V-Esame dei carboni provenienti dallo scavo dell' impianto metallurgico: Studi Etruschi, v. 11, p. 331-333.

Vallet, G., and Villard, F., 1960, Les fouilles de Megara Hyblaea (1949-1959) : Boll. Arte, v. 45 , no. 3 , p. $263-273$.

Villaret Rochov. M. von, 1957, Die Pflanzenreste der Bronzezeitlichen Pfalbauten von Valeggio am Mincio: Bericht über das Geobotan. Forch., Institüt Rübel Zürich, p. 96.

Vries, HI. de, and Barendsen, G. W., 1954, Measurements of age by the carbon-14 technique: Nature, v. 174, p. 1138-1146.

Vries, HI. de, Barendsen, G. W., Waterbolk, H. T., 1958, Groningen radiocarbon dates II: Science, v. 127 , p. 129-137.

Vries, Hl. de, and Waterbolk, H. T., 1958, Groningen radiocarbon dates III: Science, v. 128 , p. $1550-1556$. 